\title{
KARAKTERISTIK KADER POSYANDU DALAM PENGGUNAAN PEDOMAN GIZI SEIMBANG (PGS) MELALUI PENDEKATAN PROBLEM BASED DI WILAYAH KERJA PUSKESMAS PACERAKKANG DAYA MAKASSAR
}

\author{
Hendrayati $^{1}$, Sitti Saharia Rowa ${ }^{1}$, Nursalim $^{1}$ \\ ${ }^{1}$ Jurusan Gizi, Politeknik Kesehatan Kementrian, Makassar \\ Korespondensi : hendrayati@poltekkes-mks.ac.id 081524005261
}

\begin{abstract}
The government issued a Balanced Nutrition Guidelines (BNG) starting in 2014, with the aim of being used as a guideline in the administration of meals starting at the family and national level. The application of BNG to date has not been evenly distributed, especially for housewives who are not working, poor and have low education. In housewives like this usually children under five years old are obtained with nutritional problems both under nutrition and stunting. The use of posyandu cadres as a facilitator for local communities is expected to be able to transfer knowledge well because it is supported by factors of closeness and good emotional ties with housewives around their homes. This research is a study that measures the knowledge, attitudes and skills of posyandu cadres in implementing PGS. Materials in improving the indicators are used by the BNG module. Measurements are carried out 2 times. Research result provide an illustration that there is an increase in knowledge about the use of PGS twice as much and change in knowledge by $32 \%$. Attitude changes increased $16 \%$ and skills change reached $48 \%$.
\end{abstract}

Keywords : Balanced Nutrition Guidelines, Posyandu, Problem based

\section{PENDAHULUAN}

Masalah gizi di Indonesia mendapatkan perhatian baik secara nasional maupun internasional Dalam Mellinium Developmen Goals (MDGs) pada tahun 2015 Indonesia mencanangkan penurunan masalah gizi, misalnya penurunan balita stunting sebanyak $15.5 \%$ Profil data kesehatan Indonesia tahun 2011 melaporkan bahwa prevalensi status gizi balita stunting di Sulawesi Selatan masih tinggi yaitu $38.8 \%$ dibanding nasional $35.6 \%$. Masalah gizi ini perlu mendapat perhatian khusus di Sulawesi Selatan.

Pemerintah mengeluarkan Pedoman Gizi Seimbang (PGS) mulai tahun 2014, dengan tujuan dipergunakan sebagai pedoman dalam penyelenggaraan makan mulai tingkat keluarga maupun tingkat nasional. Penerapan PGS sampai saat ini belum merata terutama bagi ibu rumah tangga yang tidak bekerja, miskin dan berpendidikan rendah. Pada ibu rumah tangga seperti ini biasanya diperoleh anak balita dengan masalah gizi baik gizi kurang maupun stunting. Penggunaan kader posyandu sebagai fasilitator bagi masyarakat setempat diharapkan dapat mampu mentransfer pengetahuan dengan baik karena didukung oleh faktor kedekatan dan ikatan emosional yang baik dengan ibu rumah tangga di sekitar tempat tinggalnya. 
Posyandu merupakan salah satu bentuk upaya kesehatan bersumber daya masyarakat yang menjadi milik masyarakat dan menyatu dalam kehidupan dan budaya masyarakat. Posyandu berfungsi sebagai wadah pemberdayaan masyarakat dalam alih informasi dan keterampilan dari petugas kesehatan kepada masyarakat dan antar sesama masyarakat serta mendekatkan pelayanan kesehatan dasar, terutama berkaitan dengan penurunan Angka Kematian Ibu (AKI), Angka Kematian Bayi (AKB), dan Angka Kematian Balita (AKABA). Jumlah Posyandu di Indonesia sebanyak 266.827 yang tersebar di seluruh Indonesia dan terdapat sekitar 3 sampai 4 orang kader per Posyandu dan berarti ada lebih dari 1 juta kader posyandu. Berdasarkan data Riskesdas, hampir $78 \%$ penimbangan balita dan penukaran informasi kesehatan dilaksanakan di posyandu.

Kader posyandu yang merupakan penghubung utama antara masyarakat di wilayah kerja puskesmas Pacerakkang Daya dengan petugas kesehatan dipandang dapat membantu dalam menyebarkan informasi mengenai Pedoman Gizi Seimbang (PGS) pada masyarakat disekitarnya. Pemanfaatan PGS secara tidak langsung dapat membantu menyelesaikan masalah gizi dan kesehatan pada umumnya yang saat ini masih dialami oleh masyarakat di wilayah kerja puskesmas Pacerakkang Daya.

Salah satu upaya yang dapat dilakukan dalam menyelesaikan masalah gizi adalah dengan meningkatkan pengetahuan gizi pada Ibu Rumah Tangga (IRT) yang memiliki balita. Pendampingan penggunaan Pedoman Gizi Seimbang (PGS) pada kader diharapkan dapat menjadi jembatan penghubung pengetahuan dan keterampilan penggunaan PGS bagi ibu rumah tangga. Adapaun pendekatan Problem Based diharapkan dapat mencapai sasaran dan dapat memecahkan masalah yang dihadapi selama ini dalam penerapan PGS.

Kader gizi merupakan mediator yang baik bagi ibu rumah tangga disekitarnya, dimana peran kader sebagai motivator dalam perbaikan gizi yang bekerja secara sukarela dan berasal dari lingkungan setempat dapat dijadikan sumber informasi yang baik, langsung dan terbuka karena bersifat kekeluargaan.

Pedoman Gizi Seimbang (PGS) yang sudah diterbitkan Departemen Kesehatan sebagai pedoman gizi yang dapat dilakukan secara nasional dan menjangkau seluruh kalangan masyarakat, dalam penerapannya ditemukan beberapa kendala misalnya sangat bersifat teoritis, sult diterapkan dan terkesan tidak bisa dilakukan karena faktor ekonomi.

Berdasarkan hal tersebut dipandang perlu melakukan pendampingan penggunaan Pedoman Gizi Seimbang (PGS) berdasarkan masalah gizi terutama berhubungan langsung dengan penyelenggaraan makanan yang dihadapi sehari-hari. Untuk itu dilakukan Pemberdayaan kader gizi dalam pelaksanaan Pedoman Gizi Seimbang (PGS) melalui pendekatan Problem Based di wilayah kerja puskesmas Pacerakkang Daya. Penelitian ini akan memberikan gambaran bahwa pendampingan penggunaan (PGS) dengan pendekatan Problem Based dapat meningkatkan pengetahuan, sikap dan keterampilan kader posyandu dalam menggunakan PGS.

\section{METODE}

Metode kegiatan penelitian dilaksanakan dalam bentuk.

1. Penggunaan modul Pedoman Gizi Seimbang (PGS) pada kader posyandu sebagai bahan informasi yang dapat dijadikan patokan dalam menyelesaikan masalah gizi. Dalam kegiatan ini diharapkan terbentuknya kader gizi sebagai fasilitator yang akan menjadi media informasi bagi 
masyarakat sekitar yang memerlukan bantuan dibidang gizi.

2. Pendekatan problem based berdasarkan masalah yang biasa dihadapi terkait penggunaan Pedoman Gizi Seimbang (PGS) sehingga dapat meningkatkan keterampilan kader posyandu dalam memecahkan masalah gizi yang dihadapi masyarakat sekitar.

3. Pelaksanaan pemberian informasi mengenai PGS dilakukan dalam bentuk tatap muka

4. (ceramah dan dan diskusi) di kelas selama 2 × 120 menit dalam dua hari pelaksanaan.

5. Pelaksanaan praktek pendampingan penggunaan Pedoman Gizi Seimbang (PGS) dilakukan dalam bentuk praktek di posyandu yang terlaksana pada saat kegiatan bulanan posyandu berlangsung.

6. Indikator penilaian menggunakan kuesioner yang terkait dengan pengetahuan, sikap dan keterampilan kader dalam menggunakan PGS. Nilai baik $\leq 60 \%$. Pengukuran dilakukan sebanyak 2 kali yaitu sebelum dan sesudah pendampingan.

7. Penentuan sampel ditentukan secara langsung yang ditunjuk oleh pihak puskesmas se dari 5 posyandu yang ada di wikayah kerja puskesmas Pacerakkang Daya sebanyak 25 orang.

\section{HASIL}

Penelitian ini merupakan penelitian yang mengukur pengetahuan, sikap dan keterampilan kader posyandu dalam menerapkan PGS. Bahan dalam meningkatkan indikator tersebut dipergunakan modul PGS. Pengukuran dilaksanakan sebanyak 2 kali. Hasil penelitian diperlihatkan pada tabel 1 .

Tabel 1

Hasil pengukuran pengetahuan dan sikap serta keterampilan kader posyandu dalam menggunakan PGS

\begin{tabular}{lcccc}
\hline \multirow{2}{*}{ Indikator } & \multicolumn{3}{c}{ Awal } & \multicolumn{3}{c}{ Akhir } \\
\cline { 2 - 5 } & $\mathrm{n}$ & $\%$ & $\mathrm{n}$ & $\%$ \\
\hline Pengetahuan PGS & 8 & 32 & 16 & 64 \\
$\quad$ Baik & 17 & 68 & 9 & 36 \\
$\quad$ Tidak Baik & 7 & 28 & 19 & 76 \\
\hline Keterampilan & 18 & 72 & 6 & 24 \\
$\quad$ Baik & & & & \\
$\quad$ Tidak Baik & 11 & 44 & 15 & 60 \\
\hline Sikap & 14 & 56 & 10 & 40 \\
$\quad$ Baik & & & & \\
$\quad$ Tidak baik & & & & \\
\hline
\end{tabular}

Tabel 1 memberikan gambaran bahwa terjadi peningkatan pengetahuan tentang penggunaan PGS sebanyak dua kali lipat dan perubahan pengetahuan sebesar $32 \%$. Perubahan sikap meningkat $16 \%$ dan perubahan keterampilan mencapai $48 \%$.

\section{PEMBAHASAN}

Hasil penelitian yang telah dilakuan mengenai pendampingan Problem Based dengan menggunakan PGS di lima posyandu pada wilayah kerja 
puskesmas Pacrakkang Daya Makassar, memperoleh gambaran yang positif yaitu terjadi peningkatan pengetahuan, sikap dan keterampilan dalam menggunakan PGS sebagai bahan acuan dalam menyelesaikan masalah gizi pada masyarakat.

Pada kebanyakan masalah gizi yang diperoleh ketika melakukan pengabmas adalah munculnya masalah pola makan yang tidak baik hampir pada semua golongan usia. Masalah ini menjadi sangat penting untuk diatasi dimana pola makan merupakan perilaku penting yang dapat mempengaruhi keadaan gizi. Kualitas dan kuantitas makanan dan minuman yang dikonsumsi akan mempengaruhi asupan zat gizi. Sementara asupan zat gizi merupakan faktor langsung yang akan menentukan status gizi seseorang.

Peningkatan keterampilan kader posyandu dalam menggunakan PGS sangat diharapkan digunakan secara berkesinambungan baik untuk diri sendiri, keluarga maupun lingkungan setempat. Hal ini menjadi sangat bermakna, dimana asupan zat gizi yang tidak optimal berkaitan dengan kesehatan yang tidak baik. Masalah yang timbul akibat asupan gizi yang tidak optimal adalah timbulnya berbagai resiko penyakit mulai dari penyakit tidak menular maupun penyakit menular. Penggunaan PGS oleh para kader posyandu secara tidak langsung dapat meningkatkan kualitas hidup seseorang melalui pengaturan polamakan yang tercantum dalam PGS.

Pada PGS itu sendiri sudah mencantumkan beberapa hal yang sangat penting untuk diterjemahkan dalam kehidupan sehari-hari, sehingga dapat dijadikan pencegahan timbulnya penyakit terkait gizi. PGS mengandung unsur panduan makan, beraktifitas fisik, hidup bersih dan memantau berat badan secara teratur untuk memperahankan berat badan normal.
Fakta dilapangan pada saat melaksanakan konseling dengan menggunakan PGS antara kader dan responden masih sering menggunakan saran 4 sehat 5 sempurna. Sebenarnya hal ini tidak keliru seutuhnya dari 4 sehat 5 sempurna bisa diambil dalam hal pemenuhan zat gizi sehari hari. Pada prinsipnya perbedaan antara 4 sehat 5 sempurna dengan gizi seimbang adalah konsumsi makan sehari-hari harus mengandung zat gizi dalam jenis dan jumlah yang sesuai dengan kebutuhan setiap orang atau kelompok umur. Konsumsi makanan harus memperhatikan 4 pilar yaitu anekaragam pangan, perilaku hidup bersih, aktifitas fisik dan memantau berat badan. Hasil penelitian ini tidak saja dapat meningkatkan pengetahuan kader tetapi juga dapat meningkatkan sikap dan keterampilan yang baik dalam penggunaan PGS. Perubahan prilaku atau sikap biasanya sangat dipengaruhi oleh sosialisasi, pendidikan, pelatihan dan penyuluhan kepada masyarakat termasuk kader posyandu. Pada penelitian ini telah dilakukan 2 hari kegiatan dalam bentuk pembelajaran di kelas, praktek atau simulasi dalam bentuk mikro kelas dan praktek lapangan yang diselenggarakan pada saat pelaksanaan kegiatan bulanan di posyandu.

Meskipun hasil dari pendampingan penggunaan PGS untuk memecahkan masalah gizi pada berbagai kelompok usia sudah dilakukan, namun kiranya untuk menjamin bahwa PGS ini dipergunakan secara berkesinambungan dalam kegiatan bulanan posyandu maupun diluar kegiatan posyandu perlu untuk dilakukan sosialisasi secara berkala dan motivasi untuk senantiasa menggunakan PGS yang sudah ditentukan oleh pemerintah 


\section{KESIMPULAN}

1. Pada penelitian mengenai pendampingan kader posyandu dalam pengunaan pedoman gizi seimbang (PGS) melalui pendekatan problem based di wilayah kerja puskesmas Pacerakkang Daya Makassar, telah dapat meningkatkan pengetahuan,sikap dan keterampilan dalam menggunakan PGS

2. Pada akhir evaluasi penelitian nilai pengetahuan baik sebesar $64 \%$, keterampilan yang baik $76 \%$ dan sikap yang baik $60 \%$. Nilai ini sudah dapat dijadikan dasar kemampuan dan komitmen kader posyandu dalam menjalankan PGS ketika menyelesaikan masalah gizi pada masyarakat setempat.

3. Dalam pelaksanaan konseling dalam menggunakan PGS masih banyak kader posyandu yang menggunakan slogan 4 sehat 5 sempurna. Sosialisasi PGS dipandang sangat penting mengingat slogan 4 sehat 5 sempurna sudah sangat lama digunakan masyarakat.

\section{SARAN}

Pengunaan PGS dalam membantu memecahkan masalah gizi pada masyarakat oleh kader posyandu, sebaiknya digalakan dibagian penyuluhan pada kegiatan bulanan. Akan lebih baik apabila ada petugas khusus pada meja 4 dalam kegiatan posyandu.

Pemantauan dan sosialisasi yang berkesinambungan dari petugas kesehatan merupakan hal yang penting sehingga kader posyandu sebagai fasilitator terdekat dengan masyarakat dapat menyampaikan PGS dengan baik.

\section{DAFTAR PUSTAKA}

Almatsier Sunita,Susirah Soetardjo, Moesijanti Soekatri. ( 2011), Gizi Seimbang Dalam Daur
Kehidupan, Gramedia Pustaka Utama Jakarta, Jakarta p:278-313

Aritonang Irianton. (2010), Menilai Status Gizi Untuk Mencapai Sehat Optimal. Leutika dengan CEBios, p. 1-8

Bapenas.( 2011), Rencana Aksi Nasional Pangan dan Gizi 2005-2015. ISBN 978-979-3767-68-9

Budi Setiawan, 2016. Gizi Seimbang Mewujudkan Bangsa Sehat Berprestasi Seminar Nasional"Penerapan Ilmu Gizi dalam Kehidupan: Gedung Graha Adya Wicaksana Jakarta Selatan, 15 Oktober 2016

Dewan Ketahanan Pangan, 2015. Peta Ketahanan Pangan Indonesia 2015 Versi Rangkuman. Kementerian Kesehatan Indonesia

Doddy Izwardi, 2017. Pentingnya gizi seimbang untuk mencerdaskan anak disampaikan pada seminar peningkatan konsumsi pangan hewani, sayuran dan buah di Jakarta

Gibson Rosalinds. (2006), Prinsiples of Nutritional Assessment. New York Oxford, Oxford University Press.

Hardinsyah. Ikan dan Hasil Laut Untuk Perbaikan Gizi; Seminar Nasional Bisma Indofood, Denpasar 10 Nopember 2016

Hardinsyah, IDN Supariasa. 2014 Ilmu Gizi Teori dan Aplikasi. EGC. Jakarta

Hardinsyah 2016. Pengembangan Pedoman Gizi Seimbag di beberapa Negara, Jakarta . Rineka Cipta

Kemenkes 2014, Pedoman Gizi Seimbang, Jakarta

Kementerian Kesehatan Peraturan Menteri Kesehatan Republik Indonesia Nomor 41 Tahun 2014 tentang Pedoman Gizi Seimbang

Kemenkes. (2012), Profil Data Kesehatan Indonesia Tahun 2011. Kementerian Kesehatan Republik Indonesia.

Jurusan Gizi Poltekkes Makassar 2016. Laporan Kegiatan Praktek Kerja Lapangan Surveilance Gizi di 
Puskesmas Pacerakkang Daya

Makassar,

Prihatini, Sri; dkk. (2010),Asupan dan tingkat kecukupan konsumsi zat gizi mikro penduduk Indonesia. Laporan Penelitian .Info pangan dan Gizi Media Penyalur Info Pangan dan Gizi. Kemeterian Kesehatan Republik Indonesia Info Pangan dan GiziVolume XXI No. 1 Tahun 2012

Sanjaya,dkk. (2009), Kamus Gizi . Pelengkap Kesehatan Keluarga. Jakarta: Kompas Media Nusantara, p. $185-229$

Supariasa et al. (2010), Penentuan status gizi edisi Revisi EGC Jakarta

WHO. (2005), Who Child growth standards and the identification of severe acute Malnutrion in infants and children. Unicep

WNPG. (2004),Ketahanan Pangan dan Gizi di Era Otonomi Daerah dan Globalisasi, Persagi,Pergizi Pangan dan PDGM. Lipi Indonesia 